\title{
Removal of carbonaceous matters over alumina supported chromium and platinum chromium catalysts
}

\author{
Zenon Sarbak, Krzysztof Surma, Kinga Wieczorek \\ Adam Mickiewicz University, Laboratory of Adsorption and Catalysis in Environmental Protection, Faculty of Chemistry, \\ 60-780 Poznań, Poland, e-mail: sarbak@amu.edu.pl
}

Platinum, both alone and with a low and high amount of chromium as an additive supported on alumina, was studied as a catalyst. These catalysts were examined in the removal of the carbonizate as a model material. It was found that the $2 \mathrm{Cr} / \mathrm{Al}_{2} \mathrm{O}_{3}$ catalyst showed a significant increase in the catalytic activity as compared to $20 \mathrm{Cr} / \mathrm{Al}_{2} \mathrm{O}_{3}$. An addition of platinum was found to cause a decrease of activity.

Keywords: $\mathrm{Cr} / \mathrm{Al}_{2} \mathrm{O}_{3}, \mathrm{PtCr} / \mathrm{Al}_{2} \mathrm{O}_{3}, \mathrm{DTA}$, TG.

\section{INTRODUCTION}

As one of the measures taken to protect the natural environment, the EU authorities have introduced limitations on the content of harmful substances, including the diesel soot or the particulate matter, in the vehicle exhaust emissions. The complex physicochemical processes taking place in fuel combustion in diesel engines lead to the formation of soot of different chemical composition. Usually the particulate matter produced, is composed of graphite-like soot with adsorbed hydrocarbons, including the aromatic polycyclic hydrocarbons. The details of the process are presented in the monograph ${ }^{1}$ and literature ${ }^{2,3}$. A few methods for reducing the emission of the particulate matter, one of which is based on the use of catalysts, have been reported on in literature. Our group has been working on heterogenic catalysts for a few years. This paper reports on the study of catalytic oxidation of the carbonizate with the air oxygen over the oxide catalysts containing chromium or platinum-chromium supported on $\mathrm{Al}_{2} \mathrm{O}_{3}$, performed by a differential thermal analysis (DTA) and thermogravimetry $(\mathrm{TG})^{4-6}$.

\section{EXPERIMENTAL}

The catalysts were prepared by the method of „incipient wetness" in which the support was saturated with a solution of $\mathrm{Cr}\left(\mathrm{NO}_{3}\right)_{3}$ (Aldrich) or a solution of $\mathrm{Cr}\left(\mathrm{NO}_{3}\right)_{3}$ and $\mathrm{H}_{2} \mathrm{PtCl}_{6}$ (Aldrich) of definite nominal concentrations. The DTA/TG measurements were carried out on the Paulik-Paulik-Erdey OD-102 derivatograph, according to the procedure described earlier $^{4-6}$.

\section{RESULTS AND DISCUSSION}

20 mas.\% $\mathrm{Cr} / \mathrm{Al}_{2} \mathrm{O}_{3}$ and the other two contained the same amounts of $\mathrm{Cr} / \mathrm{Al}_{2} \mathrm{O}_{3}$.

The study was performed on four samples of the catalysts; the first two contained 2 and additionally $0.3 \mathrm{mas}$.\%Pt. For the sake of comparison analogous measurements were also performed without any catalysts and in the presence of the support $\left(\mathrm{Al}_{2} \mathrm{O}_{3}\right)$ type $\mathrm{C}$ (Degussa) Moreover, the effect of $\mathrm{Pt}$ addition to the chromium catalysts was evaluated relative to the performance of the 0.3 mas. $\% \mathrm{Pt} / \mathrm{Al}_{2} \mathrm{O}_{3}$ catalyst. The measurements were taken for the carbonizate (Hajnowskie Zakłady Suchej Destylacji Drewna, Hajnówka, Poland) containing $78.64 \mathrm{mas} . \% \mathrm{C}, 1.17 \mathrm{mas} . \% \mathrm{~N}$ and $1.34 \mathrm{mas} . \% \mathrm{H}$, which was well mixed with catalysts in the 29:1 ratio. The total amount of the mixture in each experiment was $600 \mathrm{mg}$. The samples were heated at the rate of $13^{\circ} / \mathrm{min}$ and at the airflow rate of $30 \mathrm{~cm}^{3} / \mathrm{min}$. The mass loss was calculated using the normalized TG curve in the range of exothermic effects.

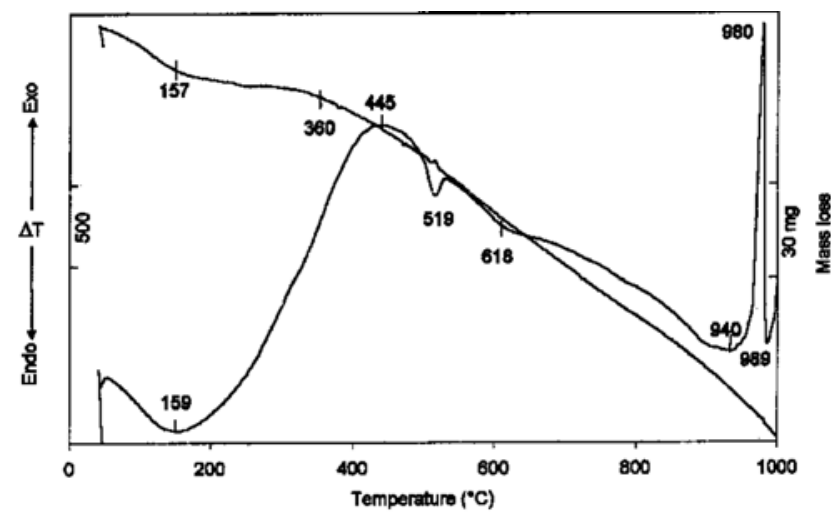

Figure 1. The DTA and TG curves of the carbonizate

Fig.1 presents the DTA and TG curves of the carbonizate. In the whole temperature range studied the mass loss has been evidenced, accompanied by endothermic effects with the minima at 159,519 and $618^{\circ} \mathrm{C}$ and the exothermic effects with the maxima at $445,980^{\circ} \mathrm{C}$ and a broad one in the range of $618-940^{\circ} \mathrm{C}$. The exothermic effect at $445^{\circ} \mathrm{C}$ is very pronounced.

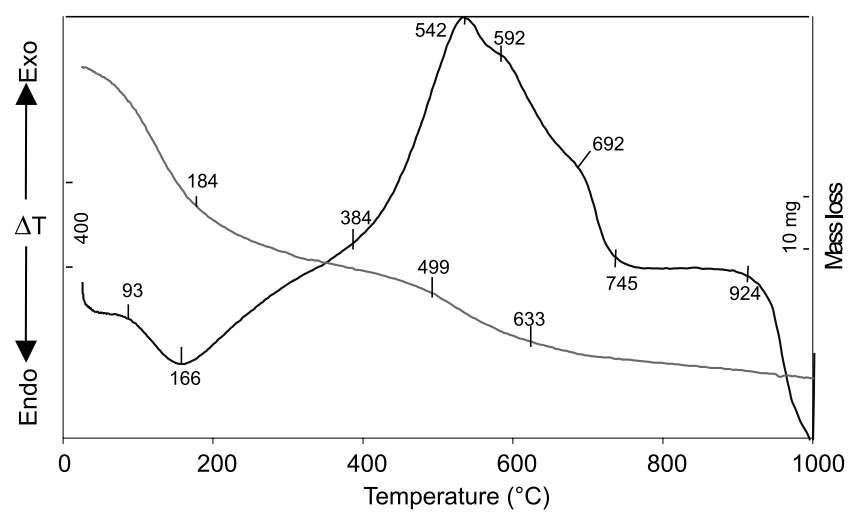

Figure 2. The DTA and TG curves of the carbonizate with $\mathrm{Al}_{2} \mathrm{O}_{3}$

The DTA and TG curves recorded for the same carbonizate heated together with the $\mathrm{Al}_{2} \mathrm{O}_{3}$ support (Fig. 2) show the exothermic effects with the maxima at different temperatures than those obtained for the pure carbonizate. The exothermic effect has been shifted from $445^{\circ} \mathrm{C}$ (Fig. 1) to $542^{\circ} \mathrm{C}$. This means that the carbonizate components manifested as the exothermic effects on the rising branch have been transformed. 
The descending branch of the exothermic effect is much steeper than the corresponding one, recorded for the carbonizate alone, which means that some of the carbonizate components showing the exothermic effects above $542^{\circ} \mathrm{C}$ have also been transformed. The changes are the consequence of the presence of $\mathrm{Al}_{2} \mathrm{O}_{3}$, which alone does not show any exothermic effects at the temperature studied, see Fig. 3.

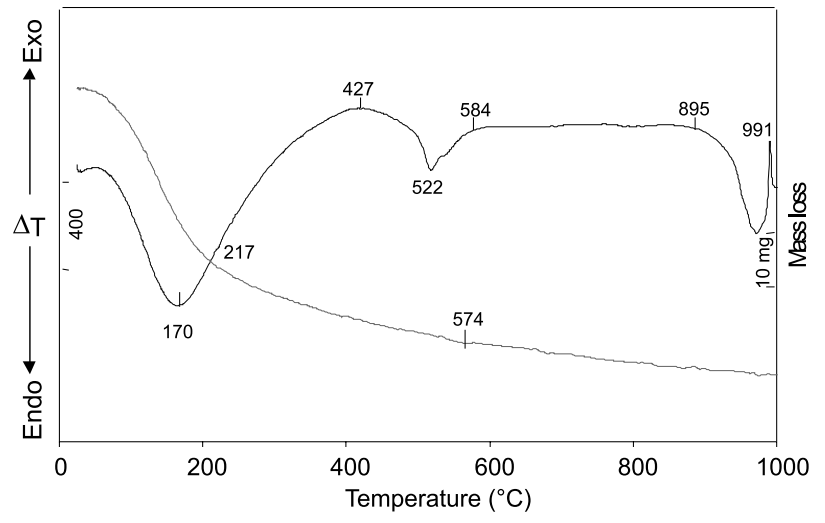

Figure 3. The DTA and TG curves of $\mathrm{Al}_{2} \mathrm{O}_{3}$

As the main aim of the reaction is the elimination of the carbonizate by its oxidising gasification, the catalytic activity of the samples studied has been assessed on the basis of the mass loss calculations presented in Table 1 .

The results obtained for the carbonizate and $\mathrm{Al}_{2} \mathrm{O}_{3}$ reveal a distinct thermocatalytic effect, however, it does not lead to the gasification of the carbonizate but only to a transformation of some of its components into others. The introduction of $\mathrm{Cr}^{3+}$ ions onto the $\mathrm{Al}_{2} \mathrm{O}_{3}$ support results in the gasification of the carbonizate. As follows from Table 1, their presence can lead to a mass loss of the carbonizate by over $30 \mathrm{mg} / \mathrm{g}$.

Table 1. The carbonizate mass loss on oxidation

\begin{tabular}{|l|c|}
\hline \multicolumn{1}{|c|}{ Catalyst } & \multicolumn{1}{|c|}{$\begin{array}{c}\text { Mass loss } \\
(\mathrm{mg} / \mathrm{g})\end{array}$} \\
\hline $\mathrm{Al}_{2} \mathrm{O}_{3}$ & 0 \\
$2 \%$ mas. $\mathrm{Cr} / \mathrm{Al}_{2} \mathrm{O}_{3}$ & 31 \\
$20 \%$ mas. $\mathrm{Cr} / \mathrm{Al}_{2} \mathrm{O}_{3}$ & 34 \\
$0,3 \%$ mas $\mathrm{Pt} / \mathrm{Al}_{2} \mathrm{O}_{3}$ & 25 \\
$0,3 \%$ mas. $\mathrm{Pt}-2 \%$ mas. $\mathrm{Cr} / \mathrm{Al}_{2} \mathrm{O}_{3}$ & 27 \\
$0,3 \%$ mas. $\mathrm{Pt}-20 \%$ mas. $\mathrm{Cr} / \mathrm{Al}_{2} \mathrm{O}_{3}$ & 20 \\
\hline
\end{tabular}

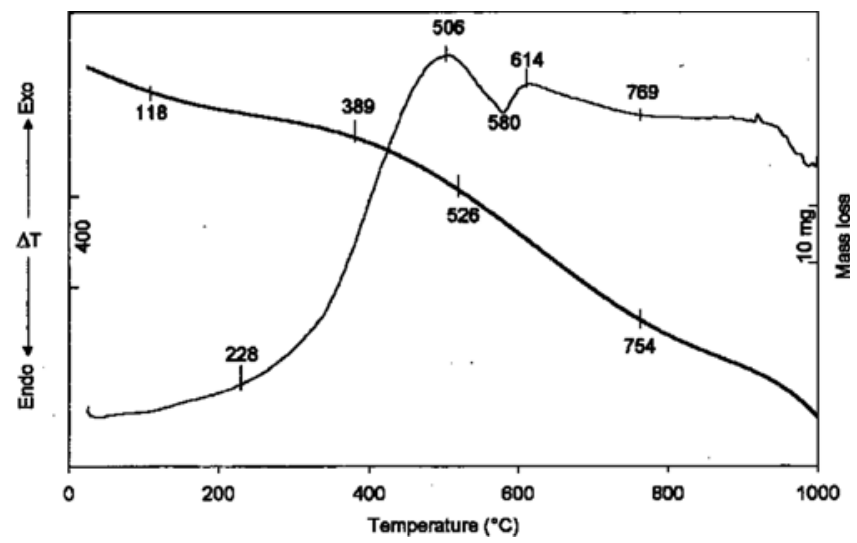

Figure 4. The DTA and TG curves of the carbonizate with 2mas. $\% \mathrm{Cr} / \mathrm{Al}_{2} \mathrm{O}_{3}$

Figs. 4 and 5 present the changes in the course of the DTA and TG curves caused by the presence of $\mathrm{Cr}^{3+}$ ions. In the DTA curve the exothermic effect maximum is shifted from $445^{\circ} \mathrm{C}$ for the carbonizate without the catalyst to $506^{\circ} \mathrm{C}$ for the carbonizate with the catalyst containing $2 \mathrm{mas} . \% \mathrm{Cr} / \mathrm{Al}_{2} \mathrm{O}_{3}$. An

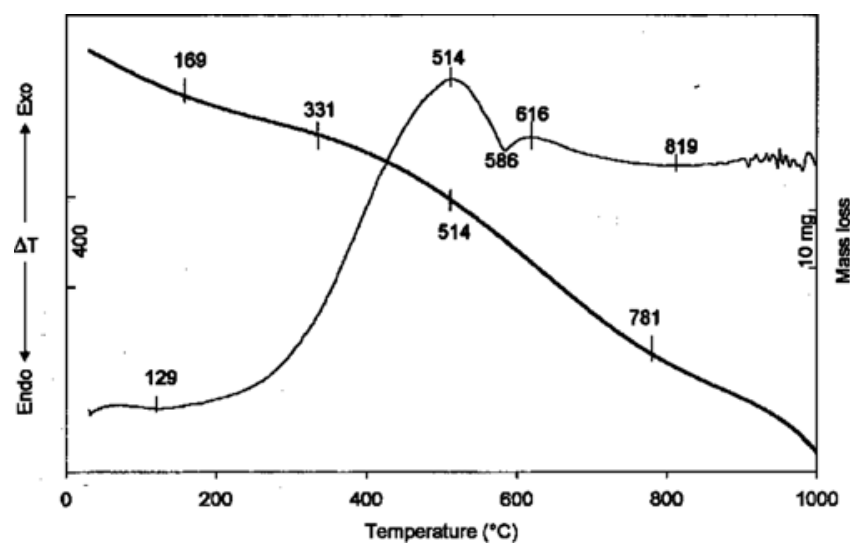

Figure 5. The DTA and TG curves of the carbonizate with 20mas. $\% \mathrm{Cr} / \mathrm{Al}_{2} \mathrm{O}_{3}$

increase in the $\mathrm{Cr}$ concentration to $20 \mathrm{mas} . \%$ has no significant effect on the catalytic activity (Table 1). The results show that the carbonizate components undergoing the oxidising gasification are those that correspond to the exothermic effects below $506^{\circ} \mathrm{C}$, in the presence of $2 \mathrm{mas} . \% \mathrm{Cr} / \mathrm{Al}_{2} \mathrm{O}_{3}$ (Fig.4) and below $514^{\circ} \mathrm{C}$, in the presence of 20 mas. $\% \mathrm{Cr} / \mathrm{Al}_{2} \mathrm{O}_{3}$ (Fig.5). The effects are only a consequence of the presence of chromium groups. As follows from the data presented in Table 1, an addition of 0.3 mas. $\%$ platinum to the samples already containing chromium leads to a decrease in the gasification of the carbonizate by $16 \%$ relative to that obtained in the presence of 2 mas. $\% \mathrm{Cr} / \mathrm{Al}_{2} \mathrm{O}_{3}$ and by $41 \%$ relative to that obtained in the presence of 20 mas. $\% \mathrm{Cr} / \mathrm{Al}_{2} \mathrm{O}_{3}$. It has been shown that the activity of the 0.3 mas. $\% \mathrm{Pt} / \mathrm{Al}_{2} \mathrm{O}_{3}$ system in the gasification of the carbonizate is much lower than that of $\mathrm{Cr} / \mathrm{Al}_{2} \mathrm{O}_{3}$. However, it should be emphasised that the presence of 0.3 mas. $\%$ of platinum alone supported on $\mathrm{Al}_{2} \mathrm{O}_{3}$ strongly increases the gasification of the carbonizate relative to that in the presence of $\mathrm{Al}_{2} \mathrm{O}_{3}$ only. The course of the DTA curve of the carbonizate in the presence of $0.3 \mathrm{mas} . \% \mathrm{Pt} / \mathrm{Al}_{2} \mathrm{O}_{3}$ (Fig.6) is similar to those presented in Figs. 4 and 5.

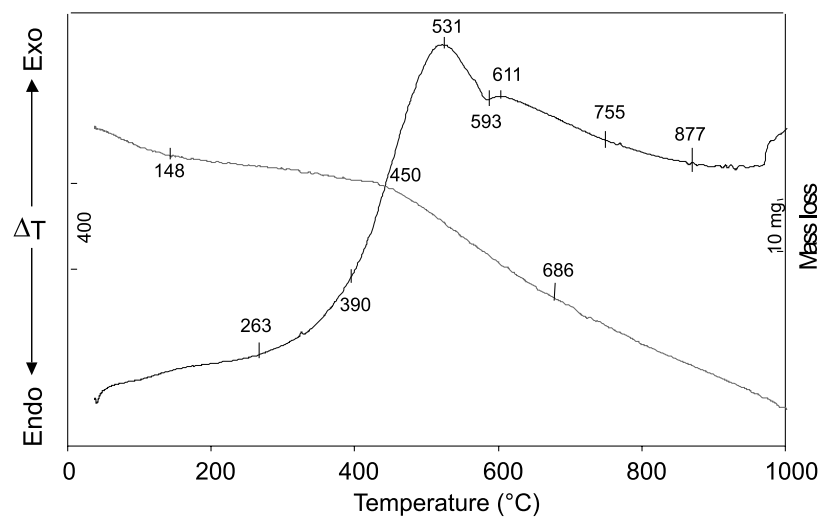

Figure 6. The DTA and TG curves of the carbonizate in the presence of 0.3 mas. $\% \mathrm{Pt} / \mathrm{Al}_{2} \mathrm{O}_{3}$

The only difference in the oxidising gasification of the carbonizate is the effectiveness leading to the elimination of the carbonizate components corresponding to the exothermic maxima below $531^{\circ} \mathrm{C}$. The course of the DTA curves for the carbonizate in the presence of the catalysts of 0.3 mas. $\% \mathrm{Pt}$ $\mathrm{Cr} / \mathrm{Al}_{2} \mathrm{O}_{3}$ (Fig. 7 and 8 ) demonstrates only small differences in the positions of the extremes, while their shape is similar to those in Fig. 4 and 5. 


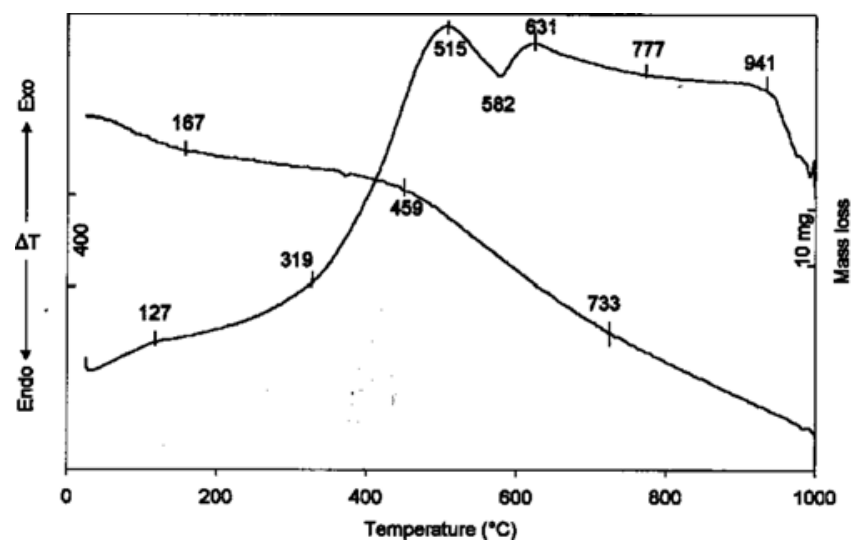

Figure 7. The DTA and TG curves of the carbonizate in the presence of 0.3 mas. $\% \mathrm{Pt}-2$ mas. $\% \mathrm{Cr} / \mathrm{Al}_{2} \mathrm{O}_{3}$

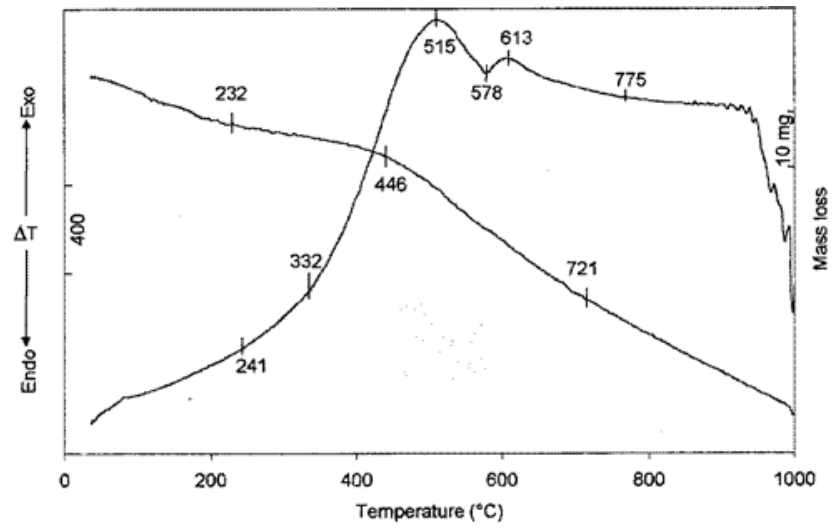

Figure 8. The DTA and TG curves of the carbonizate in the presence of 0.3 mas. $\% \mathrm{Pt}-20 \mathrm{mas}$. $\% \mathrm{Cr} / \mathrm{Al}_{2} \mathrm{O}_{3}$

\section{CONCLUSION}

As follows from the above presented results, an introduction of a small amount (2\% mas.) of chromium (III) ions onto the surface of $\mathrm{Al}_{2} \mathrm{O}_{3}$ results in a significant increase in the catalytic gasification of the carbonizate, while the introduction of the ten times greater amount of these ions causes only a small further increase in this process. The results obtained after the introduction of 0.3 mas. $\%$ Pt into the $\mathrm{Cr} / \mathrm{Al}_{2} \mathrm{O}_{3}$ systems were rather surprising. An addition of platinum was found to cause a relatively great reduction in the gasification of the carbonizate, which may be related to the formation of less active surface catalytic centres. It should be noted that in the presence of platinum alone supported on $\mathrm{Al}_{2} \mathrm{O}_{3}$ the catalytic activity of this system in the carbonizate gasification is much greater than that of $\mathrm{Al}_{2} \mathrm{O}_{3}$. The presence of the support stimulates only the transformation of some components of the carbonizate without its gasification.

\section{LITERATURE CITED}

1. Sarbak, Z. (2004). Kataliza w ochronie środowiska. Poznań, Wydawnictwo Naukowe UAM.

2. Neeft, J. (1995). Catalytic oxidation of soot. Published doctoral dissertation, Technical University of Delft, Netherland.

3. Zhao, Z., Obuch, A., Uchisawa, J. \& Kushiyama, S. (1999). In Study and technology in catalysis (pp.387 - 393). Tokyo: Kodansha.

4. Sarbak, Z. \& Surma, K. (2002). Differential thermal analysis and thermal gravimetry as fast methods to test catalytic oxidation of carbon particulates. In E.G. Derouane et.al.(Eds.), Principles and methods for accelerated catalysts de- sign and testing (pp.423 - 428). Dordrecht, : Kluwer Academic Publisher.

5. Sarbak, Z. (2003). Zastosowanie różnicowej analizy termicznej oraz termograwimetrii w katalitycznym usuwaniu sadzy. Przem. Chem. 83, 152 - 157.

6. Sarbak, Z. \& Surma, K. (2003). DTA and TG studies of catalytic oxidation of carbon particles over $\mathrm{M}_{2}{ }^{\mathrm{III}} \mathrm{O}_{3}\left(\mathrm{M}^{\mathrm{III}}=\mathrm{Al}\right.$., $\mathrm{Cr}, \mathrm{Fe}, \mathrm{Ni}$ ). J. Therm. Anal. Calorim. 72, 159 - 163. 